\title{
Pernikahan yang Dilakukan Janda Pegawai Negeri Sipil untuk Mempertahankan Uang Pensiun Janda Di Kabupaten Pamekasan)
}

\author{
Diana Merytasari \\ (Fakultas Syariah IAIN Madura, Jl. Raya Panglegur km. 4, Pamekasan, \\ email: dianamerytasari@yahoo.com)
}

\begin{abstract}
Abstrak:
Tujuan penelitian ini unutk mengetahui bagaimana pernikahan yang dilakukan oleh janda Pegawai Negeri Sipil untuk mempertahankan uang pensiun janda. Kedua, unutk mengeahui pandangan hukum Islam mengenai uang pensiun janda Pegawai Negeri Sipil yang menikah lagi. Penelitian ini menggunakan pendekatan kualitatif, dengan prosedur pengumpulan data menggunakan observasi nonpartisipan, wawancara semi terstruktur dan dokumentasi. Informan dalam penelitian ini adalah janda Pegawai Negeri Sipil.Hasil penelitian ini menunjukkan bahwa: pertama, pernikahan yang dilakukan oleh janda Pegawai Negeri Sipil untuk mempertahankan uang pensiun jandanya yaitu menikah secara sirri. Pernikahan sirri dilakukan dengan mengundang kiyai dan kelurga terdekat. Pernikahan dilakukan atas restu dari keluarga kedua belah pihak. Pernikahan yang mereka lakukan sah menurut hukum Islam. Hanya saja mereka tidak mencatatkannya di Kantor Urusan Agama. Kedua, pandangan hukum Islam mengenai uang pensiun janda tersebut adalah haram. Karena janda Pegawai Negeri tersebut sudah tidak berhak atas uang pensiun jandanya. Sedangkan janda tersebut sudah menjadi tanggungan suaminya yang sekarang. Karena janda tersebut tetap menggunakan uang pensiun janda tersebut maka termasuk dalam kategori ghasab yaitu memakan hak orang lain. Dan ghasab tersebut hukumnya haram.
\end{abstract}

Kata Kunci:

Pernikahan, Uang Pensiun Janda 


\section{Pendahuluan}

Nikah adalah peristiwa besar dalam kehidupan manusia. Sesuatu yang sebelumnya haram, dengan sarana pernikahan berubah menjadi halal. Implikasinya besar dan beragam. Pernikahan adalah sarana awal mewujudkan sebuah tatanan masyarakat, karena keluarga adalah pilar penyokong kehidupan masyarakat. Jika keluarga baik dan berkualitas, bisa dipastikan bangunan masyarakat yang diwujudkan akan kokoh dan baik. Oleh karena itu, Nabi menganjurkan betul umatnya untuk menikah. Sabda beliau: "Nikahlah dan perbanyak anak. Karena Aku bisa membanggakan diri di hadapan umatumat lain, kelak pada hari kiamat."1

Dalam Kompilasi Hukum Islam di Indonesia-Inpres No. 1 Tahun 1991 mengartikan perkawinan adalah pernikahan, yaitu akad yang sangat kuat atau mitsaaqan ghalidhan untuk menaati perintah Allah dan melaksanakannya merupakan ibadah. ${ }^{2}$ Pada hakikatnya, akad nikah adalah pertalian yang teguh dan kuat dalam hidup dan kehidupan manusia, bukan saja antara suami dan istri dan keturunannya, melainkan antara dua keluarga. Baiknya pergaulan antara istri dan suaminya, kasih-mengasihi, akan berpindah kepada semua keluarga kedua belah pihak, sehingga mereka menjadi integral dalam segala urusan sesamanya dalam menjalankan kebaikan dan mencegah segala kejahatan. Selain itu, dengan pernikahan, seseorang akan terpelihara dari godaan hawa nafsunya.

Sabda Rasulullah Saw:

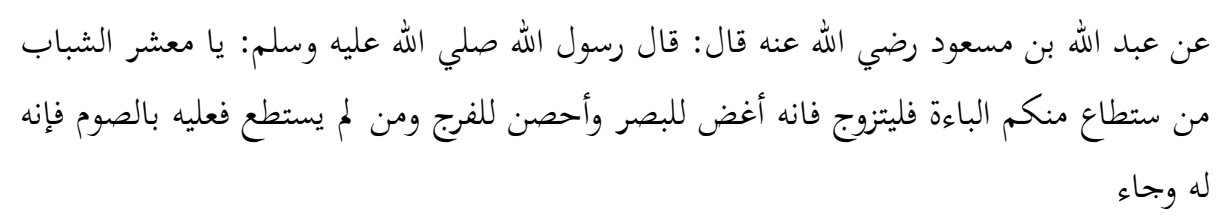

Artinya: "Hai pemuda-pemuda, barang siapa diantara kamu yang mampu serta berkeinginan hendak menikah, hendaklah dia menikah. Karena sesungguhnya pernikahan itu dapat merundukkan pandangan mata terhadap orang yang tidak halal dilihatnya, dan akan memeliharanya dari godaan

\footnotetext{
1 Abdul Djalil, Fiqh Rakyat, Imam Nakha'i, ed. M. Dedy Wahyuddin, et. Al., (Yogyakarta: Lkis Yogyakarta, 2000),. 285.

${ }^{2}$ Abd Shomad, Hukum Islam Penormaan Prinsip Syariah Dalam Hukum Indonesia, (Jakarta: Kencana, 2010),. 274.
} 
syahwat. Lalu, barang siapa yang tidak mampu menikah, hendaklah dia puasa, karena dengan puasa hawa nafsunya terhadap perempuan akan berkurang."3

Karena sifatnya yang menjangkau kehidupan luas di luar keluarga, pernikahan memiliki makna sangat strategis dalam kehidupan sebuah bangsa. Dalam konteks ini, pemerintah menjadi berkepentingan untuk mengatur institusi pernikahan, agar tatanan masyarakat yang teratur dan tentram bisa diwujudkan. UndangUndang No.1 Tahun 1974 adalah bentuk konkrit pengaturan negara tentang pernikahan. Dalam Undang-Undang No. 1 Tahun 1974 Bab I disebutkan bahwa "perkawinan adalah ikatan lahir batin antara seorang pria dengan seorang wanita sebagai suami istri dengan tujuan membentuk keluarga yang bahagia dan kekal berdasarkan Ketuhanan Yang Maha Esa".

Dalam Pasal 2 ayat 2 Undang-Undang No. 1 Tahun 1974 : “Tiap-tiap perkawinan dicatat menurut peraturan perundangundangan yang berlaku". Ketentuan ini lebih lanjut diperjelas dalam Bab 11 Peraturan Pemerintah (PP) No. 9 Tahun 1975 yang intinya: sebuah pernikahan baru dianggap memiliki kekuatan hukum di hadapan undang-undang jika dilaksanakan menurut aturan agama dan telah dicatatkan oleh pegawai pencatat perkawinan yang ditentukan undang-undang. Aturan inilah yang akhir-akhir ini menimbulkan satu istilah yang disebut sebagai: nikah sirri atau nikah di bawah tangan.

Aturan pencatatan nikah ini sebenarnya memiliki tujuan yang bagus. Namun, ketika dihadapkan dengan kenyataan, sering mengalami kesenjangan. Banyak pernikahan yang oleh karena alasanalasan tertentu tidak dicatatkan sebagaimana yang dituntut oleh undang-undang. Bisa jadi karena alasan ketidakmampuan untuk membiayai mengurus pencatatan. Atau karena suami istri belum siap hidup sebagaimana normalnya orang berkeluarga, sementara tuntutan pengabsahan (ketidakharaman) berhubungan mendesak untuk dilakukan, seperti kasus yang dihadapi oleh suami istri yang masih mondok atau kuliah. Atau karena undang-undang sendiri tidak mengizinkannya, seperti para pegawai negeri yang kawin lebih dari satu dan banyak alasan-alasan lain. Ini semua menjadikan

\footnotetext{
${ }^{3}$ Beni Ahmad Saebani, Fiqh Munakahat 1, (Bandung: Pustaka Setia, 2013), 11.
} 
pernikahan berlangsung tanpa dicatatatkan, sebagaimana dimuat dalam undang-undang. Lalu pernikahan ini disebut sebagai nikah sirri. ${ }^{4}$

Dalam konteks Indonesia, nikah sirri yang dipahami selama ini, sebenarnya bukan yang dimaksudkan oleh fiqh dengan nikah sirri. Karena kebanyakan orang melihat bahwa nikah sirri itu, adalah nikah yang tidak dicatatkan, meskipun telah memenuhi syarat dan rukun nikah, serta diketahui banyak orang. Dan nikah seperti ini dalam hukum Islam sah-sah saja, sehingga sebagai akibatnya, segala hal yang diperkenankan oleh adanya akad nikah yang sah, boleh dilakukan oleh suami istri.

Dengan begitu, kekhawatiran sebagian kalangan yang menganggap bahwa pernikahan yang tidak dicatatkan adalah tidak sah dan batal, terbantahkan dan terjawab oleh penjelasan ini. Persoalan berikutnya adalah, bagaimanapun aturan undang-undang perlu untuk diperhatikan manakala tidak ada satu hal yang mengharuskan untuk berpaling darinya sehingga, dalam kondisi ikhtiyari (normal), berpasangan suami istri sebaiknya mengikuti segala aturan undang-undang, tetapi ketika ada kebutuhan untuk melakukan pernikahan dengan tanpa dicatatkan, dan justru maslahatnya lebih besar, boleh-boleh saja pernikahan ini (dengan tidak dicatatkan) dilakukan. Dan memang, tidak cukup alasan fiqh untuk melarang dan apalagi mentidaksahkan pernikahan ini. ${ }^{5}$

Perkawinan sirri atau perkawinan di bawah tangan ialah perkawinan yang tidak memenuhi syarat dan prosedur peraturan perundangan. Terdapat perbedaan pendapat tentang sah tidaknya perkawinan di bawah tangan, dikarenakan adanya perbedaan penafsiran terhadap ketentuan Pasal 2 ayat 2 UU No. 1 Tahun 1974 tentang Perkawinan. Yang jelas ketentuan Pasal 2 ayat 2 yang mengharuskan pencatatan perkawinan terpisah dengan ketentuan Pasal 2 ayat 1 yang mengatur tentang sahnya perkawinan yang harus dilakukan menurut hukum agama dan kepercayaan. ${ }^{6}$

Akhir-akhir ini, fenomena nikah sirri menjadi tren karena dilakukan oleh semua kalangan, mulai dari masyarakat biasa,

\footnotetext{
${ }^{4}$ Abdul Djalil, Fiqh Rakyat, 286.

${ }^{5}$ Abdul Djalil, Fiqh Rakyat,. 288.

6 Abd. Shomad, Hukum Islam: Penormaan Prinsip Syari'ah dalam Hukum Indonesia, (Jakarta: Kencana, 2010),. 309.
} 
sebagian ulama, sebagian para pejabat, sebagian artis, sebagian guru dan dosen. Selain itu, yang melakukan nikah sirri banyak berstatus janda. Para wanita itu umumnya memberlakukan aturan khas, dan itu sepertinya sudah banyak dimaklumi.

Pada uraian diatas disebutkan banyak kalangan yang melakukan nikah sirri salah satunya yaitu seorang janda. Dalam hal ini yang akan dibahas mengenai pernikahan seorang janda Pegawai Negeri Sipil yang melakukan nikah sirri. Seorang janda Pegawai Negeri Sipil berhak mendapat uang pensiun janda dengan salah satu syarat dia tidak menikah lagi, jika janda tersebut menikah lagi maka uang pensiun tersebut akan dibatalkan seperti yang ada dalam Undang-Undang No. 11 Tahun 1969 tentang Uang pensiun Pegawai Negeri Dan Uang pensiun Janda/Duda Pegawai Pasal 28 ayat 1 bahwa: Uang pensiun janda/duda atau bagian uang pensiun yang diberikan janda atau duda yang tidak mempunyai anak, dicabut jika janda atau duda menikah lagi, terhitung dari bulan berikutnya perkawinan itu dilangsungkan. Bagi uang pensiun janda atau duda yang menikah lagi namun masih mempunyai seorang anak yang sah atau yang disahkan menurut undang-undang dan masih tertunjang, maka dibayarkan uang pensiun yatim piatu sampai si anak berumur 25 tahun dengan syarat belum menikah, belum bekerja atau belum berpenghasilan tetap. ${ }^{7}$

Namun berdasarkan ketentuan di atas tidak semua orang melaksanakan ketentuan tersebut, masih ada sebagian orang yang tidak mengindahkan regulasi yang ditetapkan oleh pemerintah, hal itu seperti yang terjadi di sebagian Kecamatan Pademawu. Kecamatan Pademawu merupakan salah satu kecamatan yang ada di Kabupaten Pamekasan. Penduduk Kecamatan Pademawu sebagian besar berprofesi sebagai Pegawai Negeri Sipil yaitu menjadi pegawai pemerintah. Dimana pegawai pemerintah disini mempunyai hak dan kewajiban. Salah satu hak yang didapatkan yaitu uang pensiun. Uang pensiun disini meliputi uang pensiun janda atau duda. Uang pensiun janda atau duda didapatkan jika suami atau istri yang merupakan Pegawai Negeri Sipil meninggal dunia sehingga uang pensiun tersebut diberikan kepada keluarganya. Uang pensiun janda atau duda disini mendapatkan uang pensiun sebesar $72 \%$ dari dasar uang

\footnotetext{
${ }^{7}$ Anshori, Siti Rahmah Aziz, Tafsir Tematik Isu-isu Kontemporer Perempuan,
} (Jakarta: Raja Grafindo Persada, 2014),. 122-124. 
pensiun. Akan tetapi, uang pensiun janda atau duda tersebut akan dicabut jika janda atau duda tersebut menikah lagi, terhitung dari bulan berikutnya perkawinan itu dilangsungkan.

Di Kecamatan Pademawu ada sebagian orang yang melakukan pernikahan sirri atau tidak mencatatkan pernikahannya hanya untuk mempertahankan uang pensiun tersebut. Seperti keterangan salah satu narasumber yang saya temui, beliau merupakan janda Pegawai Negeri Sipil yang melakukan nikah sirri untuk mempertahankan uang pensiun jandanya. Saya menanyakan mengapa beliau memilih tidak menikah secara resmi atau mencatatkan pernikahannya di kantor urusan agama.

“Beliau menjawab karena ada beberapa alasan salah satunya yaitu untuk mempertahankan uang pensiun jandanya dan itu sah-sah saja menurutnya karena tidak ada masalah dari pihak keluarga suami yang terdahulu." 8 Padahal, jika pernikahan tersebut diketahui maka uang pensiun tersebut secara otomatis akan dicabut dan janda tersebut wajib mengembalikan uang pensiun yang ia terima ketika menikah lagi, terhitung mulai dari bulan berlangsungnya pernikahannya. Maka berdasarkan paparan diatas menggugah hati peneliti untuk melakukan penelitian di Kecamatan Pademawu dengan judul: "Pernikahan Yang Dilakukan Janda Pegawai Negeri Sipil Untuk Mempertahankan Uang Pensiun Janda (Studi Kasus Di Kecamatan Pademawu Kabupaten Pamekasan)".

\footnotetext{
${ }^{8}$ Astuti, Ibu rumah tangga, Wawancara langsung, (11 Oktober 2018).
} 


\section{Fokus Penelitian}

Setelah dibahas dalam latar belakang masalah, maka dirasa perlu merancang rumusan masalah sebagai berikut:

1. Bagaimana pernikahan yang dilakukan oleh janda Pegawai Negeri Sipil untuk mempertahankan uang pensiun janda?

2. Bagaimana pandangan hukum Islam mengenai uang pensiun janda Pegawai Negeri Sipil yang menikah lagi?

\section{Pengertian Pernikahan}

Pernikahan atau perkawinan ialah akad yang menghalalkan pergaulan dan membatasi hak dan kewajiban antara seorang laki-laki dan perempuan yang bukan mahram. ${ }^{9}$ Allah berfirman dalam surat An-Nisa ayat 3:

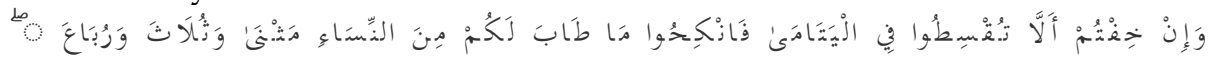

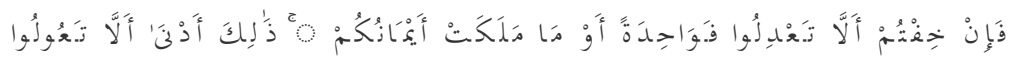

Artinya: "Dan jika kamu takut tidak akan dapat berlaku adil terhadap (hak-hak) perempuan yatim (bilamana kamu mengawininya) maka kawinilah wanita-wanita (lain) yang kamu senangi: dua, tiga, atau empat. Kemudian, jika kamu takut tidak akan berlaku adil, maka (kawinilah) seorang saja, atau budak-budak yang kamu miliki. Yang demikian itu adalah lebih dekat kepada tidak berbuat aniaya." (Q.S. An-Nisa: 3$)^{10}$

Kata "nikah" berasal dari bahasa arab نكاح yang merupakan masdar atau dari asal kata kerja نكح. Sinonimnya تزوج kemudian diterjemahkan ke dalam bahasa indonesia dengan perkawinan. Kata nikah telah dibakukan menjadi bahasa Indonesia. Oleh karena itu, secara sosial, kata pernikahan dipergunakan dalam berbagai upacara perkawinan. Di samping itu, kata pernikahan tampak lebih etis dan agamis dibandingkan dengan kata perkawinan.

\section{Tujuan Pernikahan}

Faedah yang terbesar dalam pernikahan ialah menjaga dan memelihara perempuan yang bersifat lemah dari kebinasaan. Perempuan dalam sejarah digambarkan sebagai mahluk yang sekadar menjadi pemuas hawa nafsu kaum laki-laki. Perkawinan adalah

\footnotetext{
${ }^{9}$ Saebani, Fiqh Munakahat 1., 9-10.

${ }^{10}$ Al-Qur'an, Ar-Rum (30): 21.
} 
pranata yang menyebabkan seorang perempuan mendapatkan perlindungan dari suaminya. Keperluan hidupnya wajib ditanggung oleh suaminya. Pernikahan juga berguna untuk memelihara kerukunan anak cucu (keturunan), sebab kalau tidak dengan nikah, anak yang dilahirkan tidak diketahui siapa yang akan mengurusnnya dan siapa yang bertanggung jawab menjaga dan mendidiknya. Nikah juga dipandang sebagai kemaslahatan umum, sebab kalau tidak ada pernikahan, manusia akan mengikuti hawa nafsunya sebagaimana layaknya binatang, dan dengan sifat itu akan timbul perselisihan, bencana dan permusuhan antara sesama manusia, yang mungkin juga dapat menimbulkan pembunuhan yang maha dahsyat. Tujuan pernikahan yang sejati dalam Islam adalah pembinaan akhlak manusia dan memanusiakan manusia. Hubungan yang terjadi diantara dua gender yang berbeda dapat membangun kehidupan baru secara sosial dan kultural. Hubungan dalam bangunan tersebut adalah kehidupan rumah tangga dan terbentuknya generasi keturunan manusia yang memberikan kemaslahatan bagi masa depan masyarakat dan negara.

\section{Janda Pegawai Negeri Sipil}

Janda Pegawai Negeri Sipil ialah istri sah menurut hukum dari pegawai negeri atau penerima uang pensiun pegawai yang meninggal dunia. ${ }^{11}$ Seorang janda Pegawai Negeri Sipil memiliki hak atas uang pensiun janda sebagaimana disebutkan dalam Pasal 16 ayat 1 dan Undang-Undang No. 11 Tahun 1969 tentang Uang pensiun Pegawai dan Uang pensiun Janda atau Duda Pegawai sebagai berikut: 1. Apabila Pegawai Negeri atau penerima uang pensiun pegawai meninggal dunia, maka istri (istri-istri) nya untuk Pegawai Negeri pria atau suaminya untuk Pegawai Negeri wanita, yang sebelumnya telah terdaftar pada Kantor Urusan Pegawai, berhak menerima uang pensiun janda atau uang pensiun duda.

2. Apabila Pegawai Negeri atau penerima uang pensiun pegawai yang beristri atau bersuami meninggal dunia, sedangkan tidak ada istri atau suami yang terdaftar sebagai yang berhak menerima uang pensiun janda atau duda, maka dengan menyimpang dari ketentuan pada ayat (1) pasal ini, uang pensiun

\footnotetext{
${ }^{11}$ Undang-Undang Nomor 11 Tahun 1969 tentang Uang pensiun Pegawai dan Uang
} pensiun Janda atau Duda Pegawai,. 2. 
janda atau duda diberikan kepada istri atau suami yang ada pada waktu ia meninggal dunia. Dalam hal Pegawai Negeri atau penerima uang pensiun pegawai pria termaksud diatas beristri leboh dari seorang, maka uang pensiun janda diberikan kepada istri yang ada pada waktu itu paling lama dan tidak terputusputus dinikahinya. ${ }^{12}$

\section{Uang pensiun Janda Pegawai Negeri Sipil}

Menurut Sastra Djatmika SH dan Drs Marsono, Uang pensiun adalah penghasilan yang diterima setiap bulan oleh seorang bekas pegawai yang tidak dapat bekerja lagi, untuk membiayai kehidupan selanjutnya agar tidak terlantar apabila tidak berdaya lagi untuk mencari penghasilan yang lain. ${ }^{13}$

Berdasarkan Undang-undang Nomor 11 Tahun 1969, Uang pensiun adalah jaminan hari tua dan sebagai balas jasa terhadap Pegawai Negeri yang telah bertahun-tahun mengabdikan dirinya kepada Negara. Pada pokoknya adalah menjadi kewajiban setiap orang untuk berusaha menjamin hari tuanya, dan untuk ini setiap Pegawai Negeri Sipil wajib menjadi peserta dari suatu badan asuransi sosial yang dibentuk oleh pemerintah. Karena uang pensiun bukan saja sebagai jaminan hari tua, tetapi juga adalah sebagai balas jasa, maka Pemerintah memberikan sumbangannya kepada Pegawai Negeri. ${ }^{14}$

\section{Besarnya Uang pensiun Janda Pegawai Negeri Sipil}

Besarnya uang pensiun janda atau duda sebulan adalah $36 \%$ (tiga puluh enam perseratus) dari dasar uang pensiun, dengan ketentuan bahwa apabila terdapat lebih dari seorang istri yang berhak menerima uang pensiun janda, maka besarnya bagian uang pensiun janda untuk masing-masing istri adalah 36\% (tiga puluh enam perseratus) dibagi rata antara istri-istri itu. Jumlah 36\% (tiga puluh enam perseratus) dari dasar uang pensiun termaksud tidak boleh kurang dari 75\% (tujuh puluh lima perseratus) dari uang pokok

\footnotetext{
${ }^{12}$ Undang-Undang Nomor 11 Tahun 1969., 5.

13 Sastra Djatmika dan Marsono, Hukum Kepegawaian Indonesia, (Jakarta: Djambatan, 1995),. 260.

${ }^{14}$ Undang-Undang Nomor 11 Tahun 1969., 1.
} 
terendah menurut Peraturan Pemerintah tentang uang dan pangkat Pegawai Negeri yang berlaku bagi almarhum suami atau istrinya.

Apabila Pegawai Negeri meninggal dunia, maka besarnya uang pensiun janda adalah $72 \%$ (tujuh puluh dua perseratus) dari dasar uang pensiun, dengan ketentuan bahwa apabila terdapat lebih dari seorang istri yang berhak menerima uang pensiun janda maka besarnya bagian uang pensiun janda untuk masing-masing istri $72 \%$ (tujuh puluh dua perseratus) dibagi rata antara istri-istri itu. ${ }^{15}$

Syarat-syarat Penerima Uang pensiun Pegawai Negeri Sipil

a. Keluarga dari pegawai atau penerima uang pensiun.

b. Terdaftar sebagai yang berhak menerima uang pensiun janda atau duda.

\section{METODE PENELITIAN}

Penelitian ini menggunakan penelitian kualitatif yakni multimetode dalam fokus, termasuk pendekatan interpretif dan naturalistik terhadap persoalannya. Penelitian kualitatif juga mempelajari segala sesuatu dalam latar alamiahnya, berusaha untuk memahami atau menginterpretasi fenomena dalam hal makna-makna yang orang-orang berikan pada fenomena tersebut. Alasan peneliti menggunakan penelitian kualitatif karena penelitian kualitatif dapat digunakan untuk mengungkap dan memahami apa yang terletak di balik fenomena apa saja yang sedikit belum diketahui. ${ }^{16} \mathrm{Hal}$ ini berarti bahwa peneliti kualitatif mempelajari benda-benda di dalam konteks alaminya yang berupaya untuk memahami atau menafsirkan fenomena dilihat dari makna yang diletakkan peneliti kepadanya. ${ }^{17}$

Jenis penelitian yang digunakan yakni penelitian fenomenologi. Penelitian fenomenologi yaitu penelitian kualitatif yang berupaya menggali apa saja yang tidak tampak dari perbuatan yang tampak.

\section{Kehadiran Peneliti}

Kehadiran peneliti di lapangan merupakan salah satu langkah penting dalam penelitian yang menggunakan pendekatan kualitatif.

15 Sudibyo Triatmojo, Hukum Kepegawaian Mengenai Kedudukan Hak Dan Kewajiban Pegawai Negeri Sipil, (Jakarta: Ghalia Indonesa, 1983),. 142.

${ }^{16}$ Rulam Ahmadi, Metodologi Penelitian Kualitatif, (Yogyakarta: Ar-Ruzz Media, 2014),. 12-15.

${ }^{17}$ Nusa Putra, Penelitian Kualitatif IPS, (Bandung: Remaja Rosdakarya, 2013),. 62. 
Kehadiran peneliti di lapangan mutlak diperlukan, karena peneliti bertindak sebagai instrument utama (the main instrument), sekaligus pengumpul data dalam rangka memperoleh validitas data yang diperlukan. Hal ini sesuai dengan pendapat Sugiyono yang menyatakan bahwa "dalam penelitian kualitatif instrumennya adalah orang atau human instrument, yaitu peneliti itu sendiri". Jadi kehadiran peneliti di lapangan berperan penting dalam rangka untuk memperoleh informasi yang diperlukan sesuai dengan tujuan penelitian. ${ }^{18}$ Sebelum terjun ke lapangan, peneliti sudah mengenal beberapa informan sebagai sumber informasi di Kecamatan Pademawu. Hal ini akan membantu mempermudah peneliti dalam melakukan penelitian atau mengumpulkan data. Jadi kehadiran peneliti di lapangan sudah diketahui statusnya sebagai peneliti oleh informan.

\section{Lokasi Penelitian}

Lokasi penelitian yaitu tempat peneliti mendapatkan informasi guna untuk membahas masalah yang dirumuskan. Lokasi penelitian ini adalah di Kecamatan Pademawu. Dalam memilih lokasi penelitian ini, salah satu pertimbangan bagi peneliti adalah: Pertama, lokasi tersebut adalah tempat yang bisa dijangkau dengan tempat tinggal peneliti, sehingga memudahkan bagi peneliti untuk melakukan penelitiannya di daerah tersebut. Kedua, terdapat permasalahan yang terkait dengan pandangan hukum Islam terhadap uang pensiun janda Pegawai Negeri Sipil yang menikah lagi di Kecamatan Pademawu. Ketiga, karena masalah yang terjadi di Kecamatan Pademawu ini sesuai dengan program studi yang ditempuh oleh peneliti di IAIN Madura yakni Al-Ahwal alSyakhsiyah.

\section{Sumber Data}

Sumber data menurut Lofland seperti yang dikutip oleh Lexy J. Moleong bahwa sumber data utama dalam penelitian kualitatif

\footnotetext{
${ }^{18}$ Sugiyono, Metode Penelitian Kuantitatif, Kualitatif, $R$ dan D (Bandung: Alfabeta, 2011),. 222-224.
} 
adalah kata-kata dan tindakan, selebihnya adalah tambahan seperti dokumen dan lain-lain. ${ }^{19}$

Data-data yang diperoleh dalam penelitian ini adalah data primer dan sekunder. Adapun yang dimaksud data primer adalah data yang diperoleh langsung dari sumbernya, diamati dan dicatat untuk pertama kalinya seperti, seorang istri (janda Pegawai Negeri Sipil) tersebut. Sedangkan data sekunder adalah sejumlah data berbentuk tulisan atau dokumen yang ada kaitannya dengan penelitian, yang didapatkan dari Kecamatan Pademawu.

\section{Prosedur Pengumpulan Data}

1. Observasi

2. Wawancara

3. Dokumentasi

\section{Analisis Data}

Analisis data adalah proses mencari dan menyusun secara sistematis data yang diperoleh dari hasil wawancara, catatan lapangan dan dokumentasi dengan cara mengorganisasikan data ke dalam kategori, menjabarkan ke dalam unit-unit, melakukan sintesa, menyusun ke dalam pola, memilih mana yang penting dan yang akan di pelajari, dan membuat kesimpulan sehingga mudah dipahami oleh diri sendiri maupun orang lain. ${ }^{20}$ Adapun tahapan teknik analisisnya adalah:

1. Cheking (pengecekan)

2. Organizing (pengelompokan)

\section{Pengecekan Keabsahan Data}

Pengecekan keabsahan data adalah suatu proses yang penting dalam sebuah penelitian yang harus dilakukan oleh setiap peneliti. Selain itu, proses pengecekan ini memiliki manfaat yang sangat besar dalam setiap penelitian. Manfaat tersebut antara lain adalah dapat mengetahui ketidak sempurnaan (kelemahan dan kekurangan) dari hasil penelitian, dengan demikian maka dapat dilakukan

\footnotetext{
${ }^{19}$ Lexy J. Moleong, Metodologi Penelitian Kualitatif (Bandung, Remaja Rosdakarya, 2017)., 186.

${ }^{20}$ Sugiyono, Metode Penelitian Kuantitatif Kualitatif dan R dan D., 244.
} 
penyempurnaan terhadap kekurangan yang ada. Adapun langkahlangkah dalam memperoleh keabsahan data adalah:

1. Kredibilitas.

2. Transferability.

3. Depenability.

4. Konfirmability. ${ }^{21}$

\section{Tahap-tahap Penelitian}

1. Tahapan refleksi (stage of reflection)

2. Tahapan perencanaan (stage of planning)

3. Tahapan memasuki lapangan (The Stage of Entry)

4. Tahapan pengumpulan data

5. Tahapan penarikan diri

6. Tahapan penulisan

\section{Paparan Data}

Pemaparan data dari hasil-hasil temuan yang diperoleh selama penelitian berlangsung, merupakan suatu hal yang sangat pokok dalam suatu penelitian. Oleh karena itu dalam bab ini, peneliti akan menyajikan dan menjelaskan hasil-hasil temuan di lapangan, baik yang berupa hasil observasi (pengamatan), wawancara maupun dari hasil analisis dokumentasi.

Berdasarkan wawancara dengan para suami janda Pegawai Negeri tersebut mereka melalukan pernikahan secara sirri. Pernikahan mereka dilakukan atas izin dari restudari keluarga masing-masing, baik dari pihak janda atau calon suami dan juga dari anak-anaknya.22 Meskipun istrinya masih mempertankan uang pensiun jandanya beliau tetap menafkahi istrinya karena sudah kewajibannya untuk menafkahinya.

\section{Temuan Penelitian}

Berdasarkan paparan data diatas, diperoleh temuan bahwa:

1. Pernikahan yang dilakukan oleh janda Pegawai Negeri Sipil untuk mempertahankan uang pensiun jandanya

a. Pernikahan yang dilakukan oleh janda Pegawai Negeri Sipil yaitu dengan melaksanakan pernikahan secara sirri.

\footnotetext{
${ }^{21}$ Sugiyono, Metode Penelitian Kuantitatif Kualitatif dan R dan D., 267-277.

${ }^{22}$ Observasi saat wawancara, tanggal 27 Januari 2018.
} 
b. Pernikahan sirri dilakukan dengan mendatangkan seorang kiyai dan dihadiri oleh keluarga terdekat.

c. Pernikahan dilakukan di rumah janda Pegawai Negeri Sipil tersebut.

d. Uang pernsiun tersebut dipertahankan untuk membantu perekonomiannya.

2. Pandangan hukum Islam terhadap uang pensiun Janda Pegawai Negeri Sipil yang menikah lagi.

a. Uang pensiun menurut janda Pegawai Negeri Sipil yaitu tunjangan yang didapatkan oleh istri seorang Pegawai Negeri Sipil yang meninggal.

b. Janda Pegawai Negeri sipil mengetagui bahwa uang pensiun yang dia dapatkan sudah bukan haknya.

c. Janda Pegawai Negeri Sipil mengetahui bahwa hukum uang pensiun tersebut haram karena sudah bukan haknya.

\section{PENUTUP}

Berdasarkan apa yang telah dipaparkan dari hasil penelitian ini, serta analisis, maka penulis menyimpulkan sebagai berikut:

1. Perkawinan yang dilaksanakan oleh janda Pegawai Negeri Sipil tersebut yaitu dengan cara menikah secara sirri. Nikah sirri yaitu pernikahan yang dilaksanakan sesuai dengan ketentuan agama yang terpenuhi syarat dan rukunnya, akan tetapi tidak dicatatkan di Kantor Urusan Agama atau lembaga resmi negara. Janda tersebut melakukan pernikahan secara sirri karena takut uang pensiun jandanya dicabut. Dan jika hal tersebut diketahui maka ia harus mengganti uang pensiun jandanya tersebut.

2. Pandangan hukum Islam terhadap uang pensiun janda Pegawai Negeri Sipil tersebut hukumnya haram. Dikatakan haram disini karena janda tersebut sudah menikah lagi, dan uang pensiun janda tersebut sudah bukan merupakan haknya. Keterangan tersebut, dapat disimpulkan bahwa perbuatan si janda termasuk kategori ghasab sehingga berkonsekwensi uang pensiunan yang diterima si istri hukumnya haram karena ia tidak berhak untuk menerimanya. Sebab pemerintah telah menetapkan bahwa orang yang berhak menerima uang pensiunan adalah istri yang bersangkutan selama belum menikah dengan pria lain.

\section{Daftar Pustaka}




\section{Al-Qur'an}

Djalil, Abdul. Figh Rakyat. Imam Nakha'i, ed. M. Dedy Wahyuddin, et. Al. Yogyakarta: Lkis Yogyakarta, 2000.

Shomad, Abd. Hukum Islam Penormaan Prinsip Syariah Dalam Hukum Indonesia. Jakarta: Kencana, 2010.

Saebani, Beni Ahmad. Fiqh Munakahat 1. Bandung: Pustaka Setia, 2013. Anshori, Siti Rahmah Aziz. Tafsir Tematik Isu-isu Kontemporer Perempuan. Jakarta: Raja Grafindo Persada, 2014.

Undang-Undang Nomor 11 Tahun 1969 tentang Uang pensiun Pegawai dan Uang pensiun Janda atau Duda Pegawai.

Djatmika, Sastra dan Marsono. Hukum Kepegawaian Indonesia. Jakarta: Djambatan, 1995.

Triatmojo, Sudibyo. Hukum Kepegawaian Mengenai Kedudukan Hak Dan Kewajiban Pegawai Negeri Sipil. Jakarta: Ghalia Indonesa, 1983.

Ahmadi, Rulam. Metodologi Penelitian Kualitatif. Yogyakarta: Ar-Ruzz Media, 2014.

Putra, Nusa. Penelitian Kualitatif IPS. Bandung: Remaja Rosdakarya, 2013.

Sugiyono. Metode Penelitian Kuantitatif, Kualitatif, $R$ dan D. Bandung: Alfabeta, 2011.

Moleong, Lexy J. Metodologi Penelitian Kualitatif. Bandung: Remaja Rosdakarya, 2017. 